\title{
Evaluation of functional disability and associated factors in the elderly
}

\section{Abstract}

Objective: To estimate the prevalence and self-reported socio-demographic and health factors associated with functional disability in basic and instrumental activities of daily living among the elderly. Method: A cross-sectional study was carried out, based on a representative sample of elderly people receiving care at a reference unit in the north of the state of Minas Gerais. The data were collected in 2015. Demographic and socioeconomic variables, morbidity, hospitalizations in the previous year, frailty (Edmonton Frail Scale), geriatric depression (GDS-15), and functional disability (Katz Index, Lawton and Brody Scales) were analyzed. Multiple analysis was performed using Poisson regression with robust variance. Results: 360 elderly people aged 65 years and over participated in the study. The prevalence of functional disability for Basic Activities of Daily Living was $21.4 \%$ while for instrumental activities it was $78.3 \%$. Functional disability in basic activities was higher among elderly males $(p=0.03)$ who had suffered strokes $(p=0.00)$ and were frail $(p=0.00)$, while for instrumental activities it was higher among older elderly persons ( $p=0.04)$; who were illiterate $(p=0.00)$, had less than five years of schooling $(p=0.02)$; had depressive symptoms $(p=0.00)$ and were frail $(p=0.00)$. It was lower among elderly persons who lived alone. Conclusion: A high prevalence of functional disability was identified among the elderly for instrumental activities of daily living, demonstrating the need for an effective and immediate approach by health professionals, who should employ preventive care in order to tackle this problem.

\footnotetext{
Universidade Estadual de Montes Claros, Centro de Ciências Biológicas e da Saúde, Departamento de Enfermagem. Montes Claros, Minas Gerais, Brasil.

2 Universidade Estadual de Montes Claros, Centro de Ciências Biológicas e da Saúde, Departamento de Enfermagem, Programa Pós-graduação em Cuidados Primários em Saúde. Montes Claros, Minas Gerais, Brasil.

3 Centro Universitário FIPMoc (UNIFIPMoc), Departamento de Medicina. Montes Claros, Minas Gerais, Brasil.

4 Universidade Estadual de Montes Claros, Centro de Ciências Biológicas e da Saúde, Departamento de Saúde Mental e Saúde Coletiva. Montes Claros, Minas Gerais, Brasil.

Bruna Menezes Aguiar' $\mathbb{D}$ Patrícia Oliveira Silval ${ }^{\mathbb{D}}$ Maria Aparecida Vieira² $\mathbb{I D}^{2}$ Fernanda Marques da Costa 3,4 (D) Jair Almeida Carneiro,4 $\mathbb{D}$

Keywords: Health of the Elderly. Activities of Daily Living. Functionality. 


\section{INTRODUCTION}

The process of aging of the population is a worldwide phenomenon that occurs slowly but gradually in developed countries but much more swiftly in emerging countries like Brazil ${ }^{1}$. With this expansion, the additional years of life should be analyzed from a qualitative standpoint, as it is essential to provide better health conditions for elderly people, so that they may experience an active, healthy and functional aging process, with regard to carrying out their needs, for as long as possible ${ }^{2}$.

Functional capacity can be defined as a set of physical and mental skills that are essential for the unaided execution of activities of daily living. For elderly people, this issue means that they are capable of carrying out activities and making decisions within their daily routine. In contrast, functional disability represents the dependence of this individual on others when carrying out such tasks ${ }^{3}$.

These tasks can be divided into three broad categories, namely: Basic Activities of Daily Living (BADL) which include basic activities such as selfcare, as determined by health, work, leisure and self-knowledge; Advanced Activities of Daily Living (AADL), a set of leisure activities, independent of work pursuits, educational activities, social participation, which depend on personal motivation; and, finally, Instrumental Activities of Daily Living (IADL), which refer to the capacity to carry out more complex activities, and which are therefore linked to the independence of the elderly person, given that some independence is necessary for executing such activities. The IADLs are characterized by work and by social contact, including meeting up with friends and participating in the community at large ${ }^{3,4}$.

As functional disability may reduce the degree of independence when carrying out basic and instrumental activities, it is important to investigate the impact that this condition has upon the general lives of elderly people and also upon the health services. Evaluating the functional disability of elderly people is extremely important, as it can provide a basis for providing high-quality care and social services ${ }^{5}$.
The main purpose of the present study was to calculate the prevalence of functional disability in basic and instrumental activities of daily living among the elderly and to examine the social, demographic and self-reported health factors associated with this phenomenon.

\section{METHOD}

This cross-sectional design and analytic study was carried out at a Reference Unit for the Health of the Elderly (RUHE) for outpatient treatment, in the northern part of the Brazilian state of Minas Gerais. This region has low Human Development Indices (HDIs), similar to those of the Brazilian Northeast, the poorest and least developed part of the country. The region is also an area of serious and unique social vulnerability ${ }^{6}$. This means that even a city of medium size suffers certain specific conditions, suggesting a need for studies focused on their specific particularities.

The subjects participating in the study were elderly people aged 65 and over, who were undergoing treatment between May and July 2015. The evaluated group was selected based on unintentional convenience sampling, based on the needs being attended to, considering the difficulties of making a random selection.

For the calculation of the sample size, a level of significance of $5 \%$ was applied, which is equivalent to a confidence interval of $95 \%$ and a tolerable sampling error of $3 \%$. This first estimate of sample size was increased by $20 \%$, in order to explore adjusted associations between the independent variables and functional disability. The minimum number was 360 elderly people.

The population sample was created based on the following criteria for inclusion: age of 65 years old or over and be undergoing treatment at the RUHE concerned. The criteria for exclusion were: any disability or incapacity which, as appraised by the family, or any hearing impairment, as yet unremedied, that would prevent the understanding of the questions asked. Disability according to the appraisal of the family was taken as a plausible measure, in the light 
of the complexity involved in the administration of a specific instrument for such an evaluation. In this case, before starting the interview, the data collection instrument was presented to the family, who then decided whether or not the elderly person was able to take part in the interview.

To carry out the multidimensional interview with the target public, the interviewers were trained and calibrated in advance (kappa $\geq 0.8$ ). The data was collected at the RUHE in both the morning and the afternoon.

The instruments for data collection, as used for this paper, were based on similar studies ${ }^{6,7}$ and were previously tested in a pilot study conducted at this same location, with 20 elderly people who were not included in the analysis. For data collection, the following instruments were used: the BADL (Katz index ${ }^{8}$ ) and IADL (the Lawton and Brody Scale ${ }^{9}$ ) scales; the Edmonton Frail Scale ${ }^{10}$, including the Clock Drawing Test ${ }^{11}$, which is part of this instrument; the Geriatric Depression Scale ${ }^{12}$, and also a questionnaire applied to the elderly person containing several social, demographic, epidemiological and clinical variables.

The independent social and demographic variables were: gender; age group (aged between 65 and 79, and aged 80 or over); white or non-white skin, as self-described; relationship status (with or without partner); living conditions (alone or with partner, family or friends); level of schooling (up to 4 years of schooling, and 5 or more years of schooling); literacy (yes or no); monthly family income (up to one Brazilian national minimum wage - MW, and more than one MW).

Clinical aspects refer to: the presence of chronic and non-contagious illnesses as self-reported, checked by means of the application of a second questionnaire to the elderly person: diabetes mellitus (DM); heart disease; bone and joint disease, stroke); symptoms of depression, according to the point score on the Geriatric Depression Scale: $\geq 6$ points or $<$ 6 points $^{12}$; records of falls; hospitalizations over the past year; and degree of frailty.

Frailty was evaluated using the point score based on the Edmonton Frail Scale - EFS ${ }^{10}$, which includes factors as follows: cognition, state of health; functional independence; social support; use of medication; nutrition; general mood; urinary continence; and functional performance. These domains are divided into 11 items, and the entire scale has scores ranging from zero to 17 points. The Edmonton Frail Scale (EFS) considers the elderly person as not frail when the score is between zero and 4 points (inclusive); vulnerable to frailty when the score is 5 or 6 points; suffering mild frailty for scores of 7 or 8 points; experiencing moderate frailty for scores of 9 or 10 points, and having severe frailty as those with scores $\geq 11$ points $^{10}$.

In this study, for data analysis, the results of the independent variable were separated into two levels: absence of frailty (final score $\leq 6$ ) and presence of frailty (final score $>6$ ).

Cognition was evaluated through the Clock Drawing Test (CDT), which is part of the instrument used for the evaluation of frailty. The interpretation of the CDT is based on a score from 0 to 5 points. Five points are awarded for a drawing of a perfect clock, with small deviations concerning the position and the spacing of the numbers acceptable; in contrast, a score of 0 is assigned to those who are unable to reproduce a drawing of a clock, and those who refuse to take the test ${ }^{11}$. The CDT was not included in the bivariate or multivariate analysis, due to the fact that its connection with functional disability is already well covered and described in specialist literature. The non-inclusion of this variable in the statistical model for analysis may allow the expression of variables as yet little explored, and which should be discussed.

Functional disability, a dependent variable, was defined based on the limitations of the BADL, which were measured by the Katz Index ${ }^{8}$. The limitations on the IADL were evaluated by the Lawton and Brody Scale, which includes more complex items of daily living. Based on the Lawton and Brody Scale ${ }^{9}$, the elderly people are considered independent for IADL when they score 27 points, while those with 26 points or less are considered dependent in this regard ${ }^{13}$.

The Katz Index establishes a point score ranging from 0 to 3 points. The elderly person is totally independent for BADL with a score of 0 ; one point is awarded to those who need the help of an accessory 
(such as walking sticks, Zimmer frames, support on furniture) to carry out activities; a score of two points means that human help is essential for the elderly person to carry our his or her tasks; and finally a score of three for BADL shows that the person is fully dependent ${ }^{8}$. Both the BADL and IADL scores have been recommended by the Brazilian Ministry of Health, and have been validated and adapted for use in Brazil ${ }^{13}$.

For the calculation of the statistical significance of this association, the Chi-squared $\left(\chi^{2}\right)$ Test was used. Prevalence ratios (PR) were calculated in order to investigate the existence of associations between different independent variables and functional disability. The adjusted prevalence ratios were obtained through multiple Poisson regression analysis with robust variance, considering the independent variables most strongly linked to functional disability in bivariate analysis (up to a level of significance less than 0.20$)$. For the final analysis, a final significance level of $0.05(p<0.05)$ was considered.

The information thus collected was analysed through the Statistical Package for the Social Sciences (SPSS), version 17.0 (SPSS for Windows, Chicago, USA). The variables with $p \leq 0.05$ were considered statistically significant.

This study was approved by the Research Ethics Committee of the Universidade Estadual de Montes Claros, under Opinion Statement No. 1,003,534, and all the participants signed a Free and Informed Consent Form (ICF).

\section{RESULTS}

A total of 360 elderly people were interviewed: $78.1 \%$ of these were female. The prevailing age group was 65 and 79 years old [the mean age was 75.14 years; $( \pm 7.6)]$. A total of $58.6 \%$ of the sample were literate; however, $85.8 \%$ had a low level of schooling, of four years at most; $62.5 \%$ of the elderly people in the sample declared themselves as white; $68.1 \%$ had a family income of more than one Brazilian national minimum wage (MW), and $83.1 \%$ lived with a partner or some other family member.

A total of $21.4 \%$ of the elderly people exhibited some functional disability for BADL, while $78.3 \%$ suffered disability for IADL. The evaluation of cognition through the Clock Drawing Test (CDT) showed that $79.2 \%$ of the elderly people evaluated had some degree of cognitive decline.

The bivariate analyses performed for functional disability for BADL and IADL and the other variables, are shown in Table 1.

We identified an association at a level of $20 \%$ $(p<0.20)$ between BADL and the other variables considered: gender; family configuration; symptoms of depression; stroke (CVA); falls; periods in hospital; and frailty. In the case of IADL, there were associations with level of schooling; family configuration; literacy (knowing how to read); age; presence of diabetes; symptoms of depression; and frailty (Table 1).

The prevalence of functional disability for BADL was greater among elderly men who had had strokes and were considered frail (Table 2).

Functional deficiency for IADL was greater among the elderly people of more advanced age; those who were illiterate; those with less than five years of schooling; those who showed symptoms of depression and those classed as frail; and lower among the elderly people who lived alone, when compared to those living with spouse, partner or family (Table 3). 
Table 1. Bivariate analyses between degrees of dependence for BADL and IADL and independent variables, in elderly people receiving care at a Reference Unit for the Health of the Elderly (RUHE) $(\mathrm{N}=360)$ in the city of Montes Claros, Minas Gerais, Brazil, 2015.

\begin{tabular}{|c|c|c|c|c|c|c|}
\hline \multirow{3}{*}{ Independent Variables } & \multicolumn{2}{|c|}{$\begin{array}{l}\text { Basic Activities } \\
\text { of Daily Living (BADL) }\end{array}$} & \multirow[t]{3}{*}{$p$-value } & \multicolumn{2}{|c|}{$\begin{array}{l}\text { Instrumental Activities } \\
\text { of Daily Living (IADL) }\end{array}$} & \multirow[t]{3}{*}{$p$-value } \\
\hline & DEP* & IND** & & DEP & IND & \\
\hline & $\mathrm{n}(\%)$ & $\mathrm{n}(\%)$ & & $\mathrm{n}(\%)$ & $\mathrm{n}(\%)$ & \\
\hline Gender & & & 0.021 & & & 0.33 \\
\hline Male & $24(30.4)$ & $55(69.6)$ & & $65(82.3)$ & $14(17.7)$ & \\
\hline Female & $53(18.9)$ & $228(81.1)$ & & $217(77.2)$ & $64(22.8)$ & \\
\hline Age & & & 0.232 & & & $<0.001$ \\
\hline Up to 79 years & $54(19.9)$ & $217(80.1)$ & & $201(74.2)$ & $70(25.8)$ & \\
\hline 80 years and over & $23(25.8)$ & $66(74.2)$ & & $81(91.0)$ & $8(9.0)$ & \\
\hline Skin & & & 0.813 & & & 0.121 \\
\hline White & $28(20.7)$ & 107(79.3) & & $100(74.1)$ & $35(25.9)$ & \\
\hline Non-white & $49(21.8)$ & $176(78.2)$ & & $182(80.9)$ & 43(19.1) & \\
\hline Marital Status & & & 0,461 & & & 0.534 \\
\hline With partner & $34(23.3)$ & $112(76,7)$ & & $112(76.7)$ & $34(23.3)$ & \\
\hline Without partner & $43(20.1)$ & $171(79,9)$ & & $170(79 . .4)$ & $44(20.6)$ & \\
\hline Literacy & & & 0,412 & & & $<0.001$ \\
\hline Yes & $42(19.9)$ & $169(80.1)$ & & $148(70.1)$ & $63(29.9)$ & \\
\hline No & $35(23.5)$ & $114(76.5)$ & & 134(89.9) & 15(10.1) & \\
\hline Schooling & & & 0,684 & & & $<0.001$ \\
\hline 5 years and over & $12(23.5)$ & $39(76.5)$ & & $23(45.1)$ & $28(54.9)$ & \\
\hline Up to 4 years & $65(21.0)$ & $244(79.0)$ & & $259(83.8)$ & $50(16.2)$ & \\
\hline Family configuration & & & 0,011 & & & $<0.001$ \\
\hline $\begin{array}{l}\text { Lives with partner, } \\
\text { family members of friends }\end{array}$ & $71(23.7)$ & $228(76.3)$ & & $242(80.9)$ & $57(19.1)$ & \\
\hline Lives alone & $6(9.8)$ & $55(90.2)$ & & $40(65.6)$ & $21(34 . .4)$ & \\
\hline Has own income & & & 0.951 & & & 0.392 \\
\hline Yes & $75(21.4)$ & $276(78.6)$ & & $276(78.6)$ & $75(21.4)$ & \\
\hline No & $2(22.2)$ & $7(77.8)$ & & $6(66.7)$ & $3(33.3)$ & \\
\hline Category of family income & & & 0.911 & & & 0.564 \\
\hline $\begin{array}{l}\text { More than } 1 \text { Brazilian Minimum } \\
\text { Wage (MW) }\end{array}$ & $52(21.2)$ & $193(78.8)$ & & 194(79.2) & $51(20.8)$ & \\
\hline $1 \mathrm{MW}$ or less & $25(21.7)$ & $90(78.3)$ & & $88(76.5)$ & $27(23.5)$ & \\
\hline Has diabetes mellitus & & & 0.901 & & & 0.181 \\
\hline Yes & $16(21.9)$ & $57(78.1)$ & & $53(72.6)$ & $20(27.4)$ & \\
\hline No & $61(21.3)$ & $226(78.7)$ & & $229(79.8)$ & $58(20.2)$ & \\
\hline Heart problem & & & 0.731 & & & \\
\hline Yes & $18(22.8)$ & $61(77.2)$ & & $65(82.3)$ & $14(17.7)$ & \\
\hline No & $59(21.0)$ & $222(79.0)$ & & $217(77.2)$ & $64(22.8)$ & \\
\hline Malignant tumour & & & 0.713 & & & 0.126 \\
\hline Yes & $4(25.0)$ & $12(75.0)$ & & 15(93.8) & $1(6.2)$ & \\
\hline No & $73(21.2)$ & $271(78.8)$ & & $267(77.6)$ & $77(22.4)$ & \\
\hline
\end{tabular}


Continuation of Table 1

\begin{tabular}{|c|c|c|c|c|c|c|}
\hline \multirow{3}{*}{ Independent Variables } & \multicolumn{2}{|c|}{$\begin{array}{l}\text { Basic Activities } \\
\text { of Daily Living (BADL) }\end{array}$} & \multirow[t]{3}{*}{$p$-value } & \multicolumn{2}{|c|}{$\begin{array}{l}\text { Instrumental Activities } \\
\text { of Daily Living (IADL) }\end{array}$} & \multirow[t]{3}{*}{$p$-value } \\
\hline & DEP* & IND** & & DEP & IND & \\
\hline & $\mathrm{n}(\%)$ & $\mathrm{n}(\%)$ & & $\mathrm{n}(\%)$ & $\mathrm{n}(\%)$ & \\
\hline Bone and joint disease & & & 0.564 & & & 0.082 \\
\hline Yes & $36(22.8)$ & $122(77.2)$ & & $117(74.1)$ & $41(25.9)$ & \\
\hline No & $41(20.3)$ & $161(79.7)$ & & $165(81.7)$ & $37(18.3)$ & \\
\hline Osteoporosis & & & 0.312 & & & 0.714 \\
\hline Yes & $30(24.4)$ & $93(75.6)$ & & $95(77.2)$ & $28(22.8)$ & \\
\hline No & $47(19.8)$ & $190(80.2)$ & & $187(78.9)$ & $50(21.1)$ & \\
\hline Stroke - CVA*** & & & $<0.001$ & & & 0.071 \\
\hline Yes & $20(52.6)$ & $18(47.4)$ & & $34(89.5)$ & $4(10.5)$ & \\
\hline No & $57(17.7)$ & $265(82.3)$ & & $248(77.0)$ & $74(23.0)$ & \\
\hline Symptoms of Depression & & & 0.012 & & & 0.011 \\
\hline None & $39(17.3)$ & $187(82.7)$ & & $157(69.5)$ & $69(30.5)$ & \\
\hline Present & $38(28.4)$ & $96(71.6)$ & & $125(93.3)$ & $9(6.7)$ & \\
\hline Falls & & & 0.064 & & & 0.091 \\
\hline No & $28(17.1)$ & $136(82.9)$ & & $122(74.4)$ & $42(25.6)$ & \\
\hline Yes & $49(25.0)$ & $147(75.0)$ & & $160(81.6)$ & $36(18.4)$ & \\
\hline Hospitalization & & & $<0.001$ & & & 0.431 \\
\hline None & $52(18.3)$ & $232(81.7)$ & & $220(77.5)$ & $64(22.5)$ & \\
\hline One or more & $25(32.9)$ & $51(67.1)$ & & 62(81.6) & 14(18.4) & \\
\hline Frailty & & & $<0.001$ & & & 0.001 \\
\hline Not frail & $15(7.9)$ & 175(92.1) & & $119(62.6)$ & $71(37.4)$ & \\
\hline Frail & $62(36.5)$ & $108(63.5)$ & & $163(95.9)$ & $7(4.1)$ & \\
\hline
\end{tabular}

*Dependent; ** Independent; ***Cerebrovascular Accident.

Table 2. Factors linked to functional disability for BADL among elderly people who have been assisted at the Reference Unit for the Health of the Elderly (RUHE) (N=360) in the city of Montes Claros (Multiple Analysis). Minas Gerais, Brazil, 2015.

\begin{tabular}{llll}
\hline Independent Variables & Adjusted PR* & CI 95\%** & $p$-value \\
\hline Gender & 1 & & 0.03 \\
Female & 1.08 & $1.00-1.17$ & \\
Male & & & 0.00 \\
CVA*** & 1 & $1.08-1.32$ & \\
No & 1.20 & & 0.00 \\
Yes & & & \\
Frailty & 1 & $1.16-1.32$ & \\
No & 1.24 & & \\
Yes & Con
\end{tabular}

$\left({ }^{*}\right)$ PR: Poisson Regression, with robust variance; $\left({ }^{*}\right)$ CI: Confidence Interval; $\left({ }^{* *}\right)$ CVA: Cerebral Vascular Accident. 
Table 3. Factors linked to functional disability for IADL among the elderly people receiving care at the Reference Unit for the Health of the Elderly (RUHE) (N=360) in the city of Montes Claros (Multiple Analysis). Minas Gerais, Brazil, 2015.

\begin{tabular}{|c|c|c|c|}
\hline Independent Variables & Adjusted PR* & CI $95 \% * *$ & $p$-value \\
\hline \multicolumn{4}{|l|}{ Age } \\
\hline Up to 79 years old & 1 & & 0.04 \\
\hline 80 years old or more & 1.06 & $1.00-1.14$ & \\
\hline \multicolumn{4}{|l|}{ Literate } \\
\hline Yes & 1 & & 0.00 \\
\hline No & 1.09 & $1.02-1.16$ & \\
\hline \multicolumn{4}{|l|}{ Schooling } \\
\hline 5 years or more & 1 & & 0.02 \\
\hline Up to 4 years & 1.22 & $1.12-1.34$ & \\
\hline \multicolumn{4}{|l|}{ Family Configuration } \\
\hline Resides with spouse, partner, family or friends & 1 & & 0.00 \\
\hline Lives alone & 0.91 & $0.84-0.98$ & \\
\hline \multicolumn{4}{|l|}{ Depression } \\
\hline No & 1 & & 0.00 \\
\hline Yes & 1.09 & $1.03-1.16$ & \\
\hline \multicolumn{4}{|l|}{ Frailty } \\
\hline No & 1 & & 0.00 \\
\hline Yes & 1.22 & $1.15-1.30$ & \\
\hline
\end{tabular}

$\left.{ }^{*}\right)$ RP: Poisson Regression, with robust variance; $(* *)$ CI: Confidence Interval.

\section{DISCUSSION}

The present study calculated the prevalence of functional disability for basic and instrumental activities of daily living among elderly persons treated at a Reference Unit for the Health of the Elderly (RUHE). In addition, it provides a discussion on the social and demographic factors inherent to the health of elderly people, which can impact functional disability.

The level of functional disability for BADL was $21.4 \%$, similar to that of a similar study conducted in Uberaba, in the state of Minas Gerais, where $17.6 \%$ of elderly people had some limitations for the execution of these activities ${ }^{4}$. In the case of IADL, functional disability came to $78.3 \%$, which was higher than the results found in separate studies carried out in 2010 and 2012 in the city of Uberaba, state of Minas Gerais, which found that $46.3 \%$ and $65.9 \%$ of the elderly people, respectively, suffered functional disability for the instrumental activities studied ${ }^{4,14}$. This fact could be due to the fact that IADL require greater physical integrity and cognitive skills than basic activities ${ }^{15}$.

The decline of functional capacity, as a rule, can be linked to social and demographic variables ${ }^{15}$, as shown in the present study. It was confirmed that functional disability for BADL was associated with the male gender, the presence of sequelae of strokes and frailty. With regard to IADL, there was an association with living alone, in which case lower functional disability was observed. Among elderly people of a more advanced age; with lower levels of schooling, who are illiterate, and who show symptoms of depression, a greater level of functional disability was observed.

In terms of the link between the male gender and greater functional disability for basic activities, gender issues should be considered, as due to cultural issues many men do not carry out or do not request help to perform basic activities which include domestic chores. Therefore, the more significant functional disability among males could be a result of social 
and cultural issues, rather than just associated with functional decline. Other factors that may contribute to functional disability among men include a greater exposure to risk in jobs requiring greater effort; cigarette smoking; routine ingestion of alcoholic beverages - and, as a result, the occurrence of chronic illnesses ${ }^{16,17}$. A study carried out in Itajurú, in the Brazilian state of Bahia, found that most males showed functional disability for the execution of these activities ${ }^{16}$.

Even though, in the present study, functional disability mainly affected men, it is more common in literature to find that women are more afflicted by functional disability ${ }^{3}$. This is due to the fact that aging occurs at different paces in men and women, as men are prone to more lethal diseases, such as cardiac ischemia, while elderly women normally acquire morbidities of lower mortality but which are chronic and may lead to functional disability. In addition, elderly women seek medical services more often, use more medications, and also show greater participation in health intervention plans ${ }^{13}$.

Elderly people who have had strokes suffer functional disability for the execution of BADL. This result is similar to that found in Goiânia, in the state of Goiás ${ }^{19}$. This means that functional disability related to strokes can be explained by the fact that this event has motor and sense-based consequences in the individual person, which makes walking independently and carrying out basic tasks related to self-care a more complex activity ${ }^{19}$.

Regarding the greater functional disability for IADL among elderly people of a more advanced age, this agrees with the findings of a similar study in the municipalities of Ilhéus (Bahia), Caratinga (Minas Gerais) and Nova Santa Rosa (Paraná) ${ }^{20}$. As age advances, functional capacity may decline, moving from more complex activities to less troublesome ones, considering that the capacity for carrying out a task requires the combination of different physiological systems ${ }^{1}$. The present study found no association between functional disability and BADLs. Different results were obtained in studies carried out in the city of Teresina (Piauí) and Montes Claros (Minas Gerais), both these studies found that age was indeed linked to functional disability, both for BADLs and IADLs ${ }^{21,1}$.
In this investigation, elderly people who were illiterate and those with few years of schooling experienced functional disability for IADL, similar to the results of a multicentric research study, that interviewed elderly people in the municipalities of Rio de Janeiro, Juiz de Fora (Minas Gerais), Campo Grande (Mato Grosso do Sul) and Cuiabá

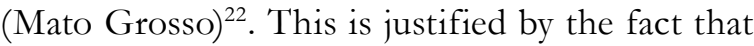
instrumental activities demand, from the elderly person, a certain level of literacy, as they are harder to execute fully ${ }^{22}$.

Schooling and literacy have an influence upon the cognitive decline of the elderly person, as can be seen in a research study that evaluated institutionalized elderly people in Araxá (Minas Gerais), showing that the elderly people with lower levels of schooling suffered greater cognitive loss, which has an effect on functional disability ${ }^{23}$.

The depressive symptoms were linked to functional disability for IADLs, which confirms the results of a study performed in Montes Claros (Minas Gerais), which identified that elderly people with symptoms of depression suffered functional disability only for instrumental activities? In this study, the presence of symptoms of depression was not linked to functional disability for BADLs. This contradicts the findings of a study carried out in the city of Santo Antonio de Jesus (Bahia), which showed functional disability both for BADLs and IADLs, among people who showed symptoms of depression ${ }^{24}$. The functional disability related to depressive symptoms is due to the fact that activities, especially instrumental ones, require more organization and articulation in their tasks, which also involves social interaction ${ }^{24}$.

In terms of the configuration of the family unit, it was observed that functional disability for IADLs was more common among the elderly who lived with others. This result was similar to that of the study carried out in the municipalities of Ilhéus (Bahia), Caratinga (Minas Gerais) and Nova Santa Rosa (Parana), which observed that the elderly people only had functional disability for IADLs ${ }^{20}$. Literature also reveals that those elderly people who lived with relatives, especially when the family unit brings together several generations, show a greater possibility of showing a decline in functional capacity 
for the accomplishment of IADLs. As a possible explanation for this fact, we can mention the fact that these elderly people are often exempted from carrying out tasks that demand a greater level of complexity ${ }^{20}$. In other words, there may not be functional decline, but rather limited autonomy.

In the present study, frailty was a key factor in establishing functional disability, both for BADLs and IADLs. This association between frailty and functional disability is similar to that obtained in a study carried out in the city of Curitiba (PR $)^{25}$. One probable justification for this is the fact that the elderly person exhibits greater limitations when exercising daily tasks, meaning that there is an initial decline in more complex activities, which require greater skill for development. Later, however, the elderly person may demonstrate difficulty in carrying out tasks of self-care ${ }^{25,26}$. A study in the city of São Carlos (São Paulo) obtained different results, however, finding that frailty was associated only with IADLs ${ }^{26}$.

It was found that the elderly people demonstrated a reduced cognitive performance, similar to the findings of a study conducted in the city of Embu das Artes (São Paulo), where it was observed that $69.9 \%$ of the elderly people evaluated obtained a negative result in the test. Failure in the CDT can also be affected by a low level of schooling, as there is a need for basic numeracy so that the clock can be constructed and the time may be read ${ }^{27}$.

The relevance of the CDT lies in the appraisal of many different cognitive areas, including memory; verbal understanding; capacity of planning; visuoconstructional skills; praxis and visual-spatial function, and so may indicate changes in the function of the frontal and the temporoparietal lobes ${ }^{28}$.

The present study contained certain limitation: notably that the transversal methodological delineation makes it more difficult to establish the causal link between functional disability among elderly people and the predisposing variables discussed in the study. In addition, the study took place in a reference unit for the health of the elderly, suggesting that the sample was convenience-based, which restricts the external validity of the research, as the results can only be applied to similar populations. In addition, the health information was self-reported by the elderly patients.

Even so, despite such limitations, this study provides a suitable sample size, as necessary for the adjustment of models of regression, and also employs standardized instruments, already adapted for Brazilian culture. Research studies with a crosssectional methodology are necessary to support local public strategies, as they provide more flexible information and can contribute to the monitoring of the real health conditions of the population.

Greater knowledge of the profile of the elderly people receiving care at the study location revealed that many suffered functional disability for some activity. This shows the need for suitably qualified health professionals who are capable of using the instruments that classify the functionality of elderly people. This in turn can enable early intervention, so as to reduce the effects of functional disability upon the quality of life of this group.

\section{CONCLUSION}

Among the elderly receiving care at the Reference Centre for the Health of the Elderly, in Montes Claros, Minas Gerais, some determining factors for functional disability for Basic Activities of Daily Life (BADLs) were identified, namely the male gender and having suffered a stroke. In contrast, functional disability for Instrumental Activities of Daily Life (IADLs) was established by factors such as: being literate; having lived longer; evidence of symptoms of depression; and living with spouses, partners, families or friends. Finally, functional disability, both for Basic and Instrumental Activities, was also determined by the frailty exhibited among the elderly people evaluated. Some degree of cognitive decline was also seen among many of the elderly people.

It is therefore essential that health professionals employ their knowledge and fulfill their role when dealing with elderly people, making use of the available tools and care systems, so as to ensure autonomy in the full evaluation of this group, as well as applying interventions in situations that present a risk for the elderly person. 


\section{REFERENCES}

1. Barbosa BR, Almeida JM, Barbosa MR, RossiBarbosa LAR. Avaliação da capacidade funcional dos idosos e fatores associados à incapacidade. Ciênc Saúde Colet [Internet]. 2014 [acesso em 28 jun. 2017];19(8):3317-25. Disponível: http://www. scielo.br/scielo.php?script=sci_arttext\&pid=S141381232014000803317\&lng=pt\&tlng=pt

2. Vicente FR, Santos SMA. Avaliação multidimensional dos determinantes do envelhecimento ativo em idosos de um município de Santa Catarina. Texto Contexto Enferm [Internet]. 2013 [acesso em 10 nov. 2017];22(2):370-8. Disponível: http://www. scielo.br/scielo.php?script $=$ sci_arttext\&pid=S010407072013000200013\&lng=pt\&tlng=pt

3. Kagawa CA, Corrente JE. Análise da capacidade funcional em idosos do município de AvaréSP: fatores associados. Rev Bras Geriatr Gerontol [Internet]. 2015 [acesso em 28 jun. 2017];18(3):577-86. Disponível: http://www.scielo. br/scielo.php?script=sci_arttext\&pid=S180998232015000300577\&lng=pt\&tlng=pt

4. Virtuoso Júnior JS, Martins CA, Roza LB, Paulo TRS, Ribeiro MCL, Tribess S. Prevalência de incapacidade funcional e fatores associados em idosos. Texto Contexto Enferm [Internet]. 2015 [acesso em 12 set. 2017];24(2):521-9. Disponível: http://www. scielo.br/scielo.php?script=sci_arttext\&pid=S010407072015000200521\&lng=en\&nrm=iso\&tlng=pt

5. Gonçalves MJC, Azevedo Júnior SA, Silva J, Souza LN. A importância da assistência do enfermeiro ao idoso institucionalizado em instituição de longa permanência. Rev Cient Enferm [Internet]. 2015 [acesso em 15 nov. 2017];5(14):12-8. Disponível: https://www.recien.com.br/index.php/ Recien/article/view/106

6. Ramos GCF, Carneiro JA, Barbosa ATF, Mendonça JMG, Caldeira AP. Prevalência de sintomas depressivos e fatores associados em idosos no norte de Minas Gerais: um estudo de base populacional. J Bras Psiquiatr [Internet]. 2015 [acesso em 12 nov. 2017];64(2):123-31. Disponível: http://www. scielo.br/scielo.php?script $=$ sci_arttext\&pid=S004720852015000200122\&lng $=$ pt\&tlng $=p t$

7. Hoffmann EJ, Ribeiro F, Farnese JM, Lima EWB. Sintomas depressivos e fatores associados entre idosos residentes em uma comunidade no norte de Minas Gerais, Brasil. J Bras Psiquiatr [Internet]. 2010 [acesso em 15 ago. 2017];59(3):191-7. Disponível: http://www. scielo.br/scielo.php?script=sci_arttext\&pid=S0047$20852010000300004 \& \operatorname{lng}=$ pt\&tlng $=$ pt
8. Katz S, Ford AB, Moskowitz RW, Jackson BA, Jaffe MW. Studies of illness in the aged. The index of ADL: a standardized measure of biological ans psychosocial function. JAMA.1963;185(12):914-9.

9. Lawton MP, Brody EM. Assessment o folder people: self-maintaining and instrumental activities of daily living. Gerontologist. 1969;9(3):179-86.

10. Rolfson DB, Majumdar SR, Tsuyuki RT, Tahir A, Rockwood K. Validity and reliability of the Edmonton Frail Scale. Age Ageing. 2006;35(5):26-9.

11. Shulman KI. Clock-drawing: is the ideal cognitive screening test? Int J Geriatr Psychiatry. 2000;15(6):548-61.

12. Yesavage JA, Brink TL, Rose TL, Lum O, Huang $\mathrm{V}$, Adey MB, et al. Development and validation of a geriatric depression screening scale: a preliminary report. J Psychiatr Res. 1983;17(1):37-49.

13. Lima IF, Azevedo RCSA, Reiners AAO, Silva AMC, Souza LC, Almeida NA. Fatores associados à independência funcional de mulheres idosas no município de Cuiabá/MT. Rev Bras Geriatr Gerontol. 2016 [acesso em 06 jul. 2017];19(5):827-37. Disponível: http://www.scielo.br/scielo.php?script $=$ sci_ arttext\&pid=S1809-98232016000500827\&lng=en\&nr $\mathrm{m}=$ iso\&tlng=pt

14. Brasil. Ministério da Saúde. Envelhecimento e Saúde da pessoa idosa [Internet]. Brasília, DF: MS; 2007 [acesso em 12 maio 2017];19. (Série A. Normas e Manuais Técnicos), (Caderno de Atenção Básica, 19). Disponível: http://bvsms.saude.gov.br/bvs/publicacoes/abcad19.pdf

15. Tavares DMS, Pelizaro PB, Pegorari MS, Paiva MM, Marchiori GF. Functional disability and associated factors in urban elderly: a population-based study. Rev Bras Cineantropom Hum [Internet]. 2016 [acesso em 05 ago. 2017];18(5):500-8. Disponível: https://periodicos.ufsc.br/index.php/rbcdh/article/ view/1980-0037.2016v18n5p499

16. Gupta P, Mani K, Rai SK, Nongkynrih B, Gupta SK. Functional disability among elderly persons in a rural area of Haryana. Indian J Public Health [Internet]. 2014 [acesso em 22 nov. 2017];58(1):12-6. Disponível: http:// www.ijph.in/article.asp?issn=0019-557X; year=2014; vol ume $=58$; issue $=1$; page $=11$; epage $=16$; aulast $=$ Gupta

17. Almeida TZS, Santos CA, Rocha SV, Pedreira RBS, Pinto Junior EP. Prevalência e fatores associados à incapacidade funcional em idosos residentes na zona rural. Rev Ciênc Méd Biol [Internet]. 2016 [acesso em 24 nov. 2017];15(2):199-203. Disponível: https:// portalseer.ufba.br/index.php/cmbio/article/view/16996 
18. Veloso MV, Figueiredo MLF, Araújo TME, Nunes BMVT, Moita Neto JM, Oliveira AV, et al. Dependência funcional em idosos institucionalizados e o déficit de memória. RIASE [Internet]. 2016 [acesso em 24 nov. 2017];2(3):663-75. Disponível: http://www.revistas.uevora.pt/index.php/saude_ envelhecimento/article/view/144

19. Castro DC, Nunes DP, Pagotto V, Pereira LV, Bachion MM, Nakatani AYK. Incapacidade funcional para atividades básicas de vida diária de idosos: estudo populacional. Ciênc Cuid Saúde [Internet]. 2016 [acesso em 05 de ago. 2017];15(1):109-117. Disponível: http://periodicos.uem.br/ojs/index.php/ CiencCuidSaude/article/view/27569

20. Vieira LA, Guedes MVC, Barros AA. Aplicação das escalas de Glasgow, Braden e Rankin em pacientes acometidos por acidente vascular encefálico. Rev Enferm UFPE on line [Internet]. 2016 [acesso em 05 ago. 2017];10(5):4226-32. Disponível https:// periodicos.ufpe.br/revistas/revistaenfermagem/ article/view/11167/12697

21. Virtuoso-Júnior JS, Menezes AS, Meneguci J, Sasaki JE. Fatores associados à incapacidade funcional em idosos brasileiros. Rev Andal Med Deporte [Internet]. 2016 [acesso em 05 ago. 2017];30(20):2-7. Disponível: https://www.sciencedirect.com/science/article/pii/ S1888754616300867?via\%3Dihub

22. Pereira LC, Figueiredo ML, Beleza CMF, Andrade EMLR, Silva MJ, Pereira AFM. Fatores preditores para incapacidade funcional de idosos atendidos na atenção básica. Rev Bras Enferm [Internet]. 2017 [acesso em 06 ago. 2017];70(1):112-18. Disponível: http://www.scielo.br/scielo.php?script=sci_ arttext\&pid=S0034-71672017000100112

23. Mattos IE, Carmo CN, Santiago LM, Luz LL. Factors associated with functional incapacity in elders living in long stay institutions in Brazil: a cross-sectional study. BMC Geriatrics [Internet]. 2014 [acesso em 06 ago. 2017];14(47):2-9. Disponível: https://bmcgeriatr. biomedcentral.com/articles/10.1186/1471-2318-14-47
24. Trindade APNT, Barboza MA, Oliveira FB, Borges APO. Repercussão do declínio cognitivo na capacidade funcional em idosos institucionalizados e não institucionalizados. Fisioter Mov [Internet]. 2013 [acesso em 06 ago. 2017];26(2):281-9. Disponível: http://www.scielo. br/scielo.php?script $=$ sci_arttext\&pid $=$ S0103$51502013000200005 \& \operatorname{lng}=\mathrm{pt} \& \operatorname{tlng}=\mathrm{pt}$

25. Possato JM, Rabelo DF. Condições de saúde psicológica, capacidade funcional e suporte social de idosos. Rev Kairós [Internet]. 2017 [acesso em 15 ago. 2017];20(2):45-57. Disponível: https://revistas.pucsp. br/index.php/kairos/article/view/34061

26. Lenardt MH, Carneiro NHK, Binotto MA, Willig MH, Lourenço TM, Albino J. Fragilidade e qualidade de vida de idosos usuários da Atenção Básica de Saúde. Rev Bras Enferm [Internet]. 2016 [acesso em 18 ago. 2017];69(3):478-83. Disponível: http://www. scielo.br/scielo.php?script=sci_arttext\&pid=S0034$71672016000300478 \& \operatorname{lng}=\mathrm{pt} \& \operatorname{tn} \mathrm{l}=\mathrm{pt}$

27. Santos-Orlandi AA, Brito TRP, Ottaviani AC, Rossetti ES, Zazzetta MS, Pavarini SCI. Idosos que cuidam de idosos: um estudo sobre a Síndrome da Fragilidade. Rev Bras Enferm [Internet]. 2017 [acesso em 18 ago. 2017];70(4):856-64. Disponível: http://www. scielo.br/scielo.php?script $=$ sci_arttext\&pid $=$ S003471672017000400822\&lng=en\&nrm=iso\&tlng $=\mathrm{pt}$

28. Fernandes HCL, Gaspar JC, Yamashita CH, Amendola F, Alvarenga RM, Oliveira MAC. Avaliação da fragilidade de idosos atendidos em uma unidade da Estratégia Saúde da Família. Texto Contexto Enferm [Internet]. 2013 [acesso em 22 nov. 2017];22(2):423-31. Disponível: http://www. scielo.br/scielo.php?script $=$ sci_arttext\&pid $=$ S010407072013000200019\&lng $=$ pt\&tlng $=$ pt

29. Moura GC, Lopes AA, Lima LD, Godoi VH, Barbosa ZCL. Avaliação de sintomas demenciais em idosos. Cad Grad Ciênc Hum. Soc. Unit [Internet]. 2017 [acesso em 22 nov. 2017];4(2):63-76. Disponível: https://periodicos.set.edu.br/index.php/fitshumanas/ article/view/4176/2578 